\title{
Peertechz
}

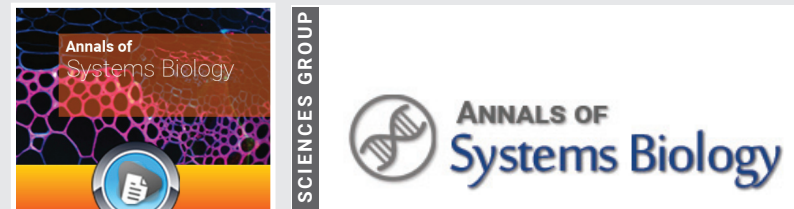

\section{Redox regulation of}

\section{adventitious root formation}

\section{through downstream changes} in hormonal system in mung bean [Vigna radiata (L.) $R$.

*Corresponding author: Soumen Bhattacharjee, Plant Physiology and Biochemistry Research Laboratory, Centre For Advanced Study, Department of Botany, University of Burdwan, Burdwan, 713104, India, Tel: 09433778493; E-mail: Soumen1995@yahoo.com, sbhattacharjee@bot.buruniv.ac.in

Keywords: Redox system; Salicylic acid; Gibberelic acid; Abscisic acid; Jasmonic acid; Adventitious root formation; Mung bean

https://www, peertechz,com

Check for updates Wilczek]

\author{
Durga Kora and Soumen Bhattacharjee* \\ Plant Physiology and Biochemistry Research Laboratory, Centre For Advanced Study, Department of \\ Botany, University of Burdwan, Burdwan, 713104, India
}

\begin{abstract}
Redox regulation on plant morphogenetic process of Adventitious Rooting (AR) can be vouched from the experimental data of redox manipulated salicylic acid treated hypocotyl explants of mung bean. In our previous work, application of pro-oxidant $\mathrm{H}_{2} \mathrm{O}_{2}(500 \mu \mathrm{M})$ followed by salicylic acid (SA, $\left.600 \mu \mathrm{M}\right)$ have been shown to significantly augment Adventitious Root Formation (ARF), whereas $10 \times 10^{-4} \mathrm{M}$ DPI (Diphenyleneiodonium, an inhibitor of NADPH-oxidase) $-600 \mu \mathrm{M} \mathrm{SA}$ and $10 \times 10^{-4} \mathrm{M}$ (Dimethylthiourea, a free radical scavenger) - $600 \mu \mathrm{M} \mathrm{SA}$ combination reduced the formation of ARF in hypocotyl explants of mung bean. In the present study, we have examined the impact of such treating conditions or redox manipulation on changes in endogenous titer of bonafide hormone system (gibberelic acid, abscisic acid, jasmonic acid) to document ROS- hormone interaction during adventitious rooting. The work suggests signinificant impact of redox manipulation on changes in endogenous titer of these hormonal system associated with AR. $500 \mu \mathrm{M} \mathrm{H}_{2} \mathrm{O}_{2}-600 \mu \mathrm{M}$ SA treatment combination, which has augmented formation of AR, has also shown higher accumulation of these hormones as compared to the untreated control. Further, DPI with or without combination of SA which inhibited the ARF, has also reduced the endogenous concentration of these Plant Growth Regulators (PGRs), suggesting role of these growth regulators in low concentration on adventitious root formation. Role of the SA signalling with prooxidant $\mathrm{H}_{2} \mathrm{O}_{2}$ as second messenger during $A R$ is suggested.
\end{abstract}

\section{Introduction}

ROS acts downstream of many signaling pathway initiated by plant growth hormones leading to the genesis of adventitious root formation [1-6]. ROS are generated in response to any physical damage or wound [7], acting as a second messenger in response $[8,9]$. Removal of primary roots may induce a wound signal including ROS that intiates ARF for water and nutrient uptake from the surroundings [3,4,10-13] Removal of primary roots increased the endogenous $\mathrm{H}_{2} \mathrm{O}_{2}$ in water treated cucumber explants in compared to the DPI (Diphenyleneiodonium, an inhibitor of NADPH-oxidase) treated explants of cucumber where the primary root removal increased the endogenous $\mathrm{H}_{2} \mathrm{O}_{2}$ but it got lowered after few hours and remained at lower concentration unlike in control treatment where it reached its higher peak after $3 \mathrm{hr}$ then declined to its lowest concentration after $11 \mathrm{~h}$, increasing again attaining second peak after $17 \mathrm{~h}$. exogenous application of $20-40 \mathrm{mM} \mathrm{H}_{2} \mathrm{O}_{2}$ or $10 \mathrm{mM}$ Indole Acetic acid (IAA) significantly increased the number of AR in cucumber seedling explants and $10-50 \mathrm{mM} \mathrm{H}_{2} \mathrm{O}_{2}$ significantly increased the fresh weight of adventitious roots. $2 \mathrm{mM}$ ascorbic acid, 100 U CAT (Catalase) or $1 \mathrm{mM}$ DPI eliminated the root promoting effect and the effects of IAA were eliminated by 4 $\mathrm{mM}$ ascorbic acid, $100 \mathrm{U}$ CAT or $5 \mathrm{mM}$ DPI which were partly rescued by exogenous $\mathrm{H}_{2} \mathrm{O}_{2}$ clearly indicating the role of $\mathrm{H}_{2} \mathrm{O}_{2}$ in ARF [14]. Recent study in cucumber, ROS, auxin and ethylene accumulated during water logged condition. Auxin and ethylene both induced the ROS generation. Both ethylene and auxin 
induced AR were inhibited by NADPH oxidase inhibitor, DPI, suggesting a significant role of ROS in AR morphogenesis [15]. The Plant growth hormones like auxin, ethylene, NO etc. make use of ROS and other PGRs like Gibberelic acid, Abscisic acid, Jasmonic acid (GA, ABA and JA) etc. in initiating ARF. ABA, GA and JA play an important role in plant responses to biotic and abiotic stress. There is less study in the direct cross talk of ROS with $\mathrm{ABA}, \mathrm{GA}$ and JA during ARF.

$\mathrm{SA}$, an endogenous plant growth regulator which is found to have both stimulatory and inhibitory effects on ARF [1621]. It works synergistically with auxin in IAA-induced ARF [22]. In a recent work, it has been shown that SA induces ARF in cucumber through competitive inhibition of the IAA-Asp synthetase activity of CsGH3.5 (Gretchen Hagen3.5) leading to the increase in free IAA content. Application of $50 \mu \mathrm{M}$ SA could lead to activation of cyclin and CDK gene expression indicating its effect on adventitious rooting during induction phase [23]. Unlike methyljasmonate, SA increased the scopolamine in adventitious root cultures of Scopolia parviflora but did not show any negative effect on root growth, infact SA exposure for relative short time and during active growth phase, all the concentation studied slightly increased the root growth index and did not stimulate root browning [24]. In a study of Tomato stem rooting, it was found that in addition to auxin, $\mathrm{ABA}$, zeatin and SA may play a complementary role in the induction, initiation and emergence of the developing AR and hormone homeostais is important during all the stages of ARF [25]. However, some workers have found that SA inhibited adventitious root formation. It decreased the weights of roots in mung bean hypocotyls cuttings [20]. It is reported to promote IAA decarboxylation and reduces rooting when applied duing the intial days when auxin enhances rooting. During the later phase, when auxin inhibits rooting, it promotes outgrowth of root primordia [21].

ROS supposed to act downstream of SA and application of ROS scavenger DMTU and NADPH Oxidase inhibitor DPI both led to the reduction of ARF in Mung bean hypocotyl $[5,16]$ Mutants in the alleles eds5-1 and eds5-2 (SA induction deficient mutant), unable to synthesize SA produces significantly lower number of ARF as compared to the wild type [16]. In most of the cases, SA found to induce ARF via up-regulation of $\mathrm{H}_{2} \mathrm{O}_{2}$ formation [16] indicating the implication of ROS $[16,18$ ] Salicylic acid increases the production of ROS via changing the antioxidative defnce system like inhibiting the activity of Catalse enzymes and increasing the activity of $\mathrm{H}_{2} \mathrm{O}_{2}$ formation enzymes $[16,26]$.

GA, a tetracyclic di-terpenoid compound, is a plant hormone involved in plant growth and development. It stimulates Dormancy, seed germination, flowering and sex expression, embryo development, trigger transitions from meristem to shoot growth, juvenile to adult leaf stage, grain development and also interacts with different environmental conditions like Light, temperature etc [29-34]. GA also has a stimulatory effect on root formation [35-37]. Gibberellic acid at low concentration $\left(10^{-9}-10^{-6} \mathrm{M}\right)$ promotes rooting, might because of mobilization of low- molecular weight carbohydrates from shoot to lower part. In low irradiance, light may modify the rooting response of GA treated cuttings of stock plants [38] Plant cuttings of Pisum sativum formed higher number of roots at an irradiance of $16 \mathrm{~W} \mathrm{~m}^{-\mathrm{e}}$ but lower rooting in higher irradiance then this [39]. GA dissolved in water promoted rooting significantly at $10^{-7} \mathrm{M}$ and $10^{-8} \mathrm{M}$ [40]. It is also suggested that root initiation required an appropriate combination of $\mathrm{GA}_{3}$ and auxin [41]. Higher $\mathrm{GA}_{3}$ or the lower IAA concentration resulted in more roots in Persicaria perfoliata [42]. GA increased the number of roots and the effect increased with concentration (from 10 and with $100 \mathrm{mg} / \mathrm{L}$ ) in stem cuttings of Ipomoea fistulosa [39]. However many work have also reported that $\mathrm{GA}_{3}$ inhibits ARF [39,43-47]. Gibberellic acid in high concentration inhibited root formation [39] and may probably inhibits the outgrowth of root primordial [40]. In some cases, GA treatment reduced the cell division in established primorida and also blocks the action of IAA in some process subsequent to the primordial initiation [48]. This inhibition might be due to a competitive diversion of mobilized reserve food materials towards the shoot than to the root meristems [47]. GA-treated barley (Hordeum vulgare) aleurone layers causes rapid death of all cells when incubated with $\mathrm{H}_{2} \mathrm{O}_{2}$ but $\mathrm{ABA}$ - treated did not cause cell death upon incubation with same. Also there was decrease in the amounts and activities of ROS scavenging enzymes, like catalase (CAT), Ascorbate Peroxidase (APX), and superoxide dismutase (SOD) in aleurone layers treated with GA. on the other hand, the amount and activity of CAT and Cat2 mRNA was found to be increased in the ABA-treated layers which also maintains high amounts of ascorbate peroxidase and superoxide dismutase, whereas GA causes rapid reduction in the amounts of these enzymes resulting in oxidative stress leading to cell death [49]. Also, it has been reported that GA-treated aleurone protoplasts are less able to tolerate endogenous or exogenously applied $\mathrm{H}_{2} \mathrm{O}_{2}$ than ABA-treated protoplasts [50]. These findings suggest that $\mathrm{GA}_{3}$ might suppress the antioxidative defence system resulting in oxidative stress and may promote ARF at low concentration by encouraging the ROS formation with downregulating effect on ROS scavenging enzymes. Gibberellins also have a negative effect on AR formation in poplar. Here the mutants gibberellins insensitive (gai) and repressor of GA1-like1 (rgl1), affected in gibberellins perception and responses to gibberellins as well, AR formation remains unaffected [51].

ABA, also called stress hormone, is an isoprenoid phytohormone [52]. It regulates various physiological roles such as stomatal closer, leaf senescence, Bud dormancy, seed germination, osmotic regulation, cuticular wax accumulation, modulation of root architecture and also it controls various downstream processes related to abiotic and biotic stresses [53,54]. Li, et al. [55] have showed that ABA promotes adventitious rooting in mung bean by reducing the activities of antioxidative enzymes (CAT, APX) and antioxidant levels (GSH AsA) similar to the work of Fath, et al. [49]. ABA also acts as a second messenger in the signaling pathway of adventitious rooting. $\mathrm{ABA}$ is found to up-regulate $\mathrm{CsHO} 1$ cucumber Heme Oxygenase (HO) gene that forms carbon monoxide that helps in the adventitious rooting [56]. Endogenous $\mathrm{H}_{2} \mathrm{O}_{2}$ was suggested to be involved in ABA-induced adventitious root development under drought stress in cucumber [57]. Later on comparative proteomic analysis of key proteins have revealed

Citation: Kora D, Bhattacharjee S (2021) Redox regulation of adventitious root formation through downstream changes in hormonal system in mung bean [Vigna radiata (L.) R. Wilczek]. Ann Syst Biol 4(1): 005-012. DOI: https://dx.doi.org/10.17352/asb.000011 
that $\mathrm{H}_{2} \mathrm{O}_{2}$ might be involved in $\mathrm{ABA}$-induced adventitious root development by regulating photosynthesis-related proteins, stress defense-related proteins, folding-, modificationand degradation-related proteins under drought stress in cucumber [58]. ABA at a concentration of $5 \times 10^{-5} \mathrm{M}$ promoted adventitious root development, and the root number increased when it is applied along with IAA [59]. In a complete opposite story, ABA is not only found to be a complete inhibitor of GA activity, also a complete inhibitor of AR formation[59]. ABA always remains highest in the non-rooting tissues [60]. But application of IAA attenuates $\mathrm{AB}$ and helps in $\mathrm{AR}$ formation [61]. Death of epidermal cells overlying the root primordia are important for the emergence of noval adventitious roots which is done by the Programmed Cell Death (PCD). PCD is induced by the ethylene with the help of ROS and also found to be promoted by GA but is blocked by the ABA [60]. It has also been reported that root emergence is dependent on $\mathrm{GA}_{3}$ activity and concentration while the growth rate of the root depends largely on GA concentration. ABA interferes with the ethylene signaling of root elongation and GA signaling inhibiting root elongation and root emergence [60]. ABA inhibits PCD and that's what may be the reason its concentration got decreased in the first few hours of submergence [60,62-64] and by ten-fold in growth responsive region of deep water rice $[60,62,63]$. It is also a negative regulator of AR development in tomatoes [65] However, it is also reported that $\mathrm{H}_{2} \mathrm{O}_{2}$ mediate the inhibition of root growth in Arabidopsis Columbia by ABA [66].

JA (3-oxo-2-2'-cis-pentenyl-cyclopentane-1-acetic acid), its methyl ester MeJA and isoleucine conjugate (JA-Ile) are considered to be plant stress hormones or endogenous plant growth regulator which comes into play in various stress responses, growth and developmental process $[67,68]$. They happen to induce stomatal opening, inhibits rubisco biosynthesis, affects nitrogen and phosphorus uptake and transport of glucose and other organic matter [28]. Jasmonate and its methylester, methyljasmonate (MeJA) was found to accumulate rapidly in wounded stems of Soybean and remained elevated up to $24 \mathrm{~h}$ and also addition of MeJA up regulated the expression of wound response genes (chalcone synthase, vegetative storage protein, and proline-rich cell wall protein) indicating its major role in wound response [69] and along with ABA, they are suggested to be mediators of wound responses in plants [69]. In contrary finding, it has been proposed that auxin promotes adventitious rooting by inducing expression of Gretchen Hagen 3 ( $\mathrm{GH}_{3}$ ) gene family, $\mathrm{GH}_{3} .3, \mathrm{GH}_{3} .5$ and $\mathrm{GH}_{3} .6$, via the positive regulators auxin response factors, ARF6 and ARF8, resulting in increased conjugated JA and thus the concentration of free JA level gets reduced. JA negatively regulates adventitious rooting through the activation of the CORONATINE INSENSITIVE1 (COI1) signaling pathway [70-73]. JA acts as a positive regulator of AR formation in Petunia cuttings [74]. The gene CbNN1 was identified in a study in Catalpa spp, which showed high expression levels in accessions with greater adventitious rooting ability [75]. CbNN1 encodes a WRKY transcription factor and its ortholog in Arabidopsis modulates the crosstalk between the salicylic acid and jasmonic acid (JA) pathways in response to a wide range of biotic and abiotic stimuli [75-77].
So, there are many works that supports both the stimulatory and inhibitory effect of ABA, GA, JA and SA in adventitious root formation. But there had been no study in the ROS- PGR interaction. In this study we have tried to explore the effect of redox modulation in SA treated hypocotyl explants on endogenous PGRs GA, ABA and JA and also endogenous ROShormone interaction during the formation of ARF.

\section{Material and method}

Fresh, viable and healthy mung bean [Vigna radiata (L.) R. Wilczek] seeds, collected from local harvest, were surface sterilized (in $0.1 \% \mathrm{HgCl}_{2}$ for $2 \mathrm{~min}$ ) and given five wash in MiliQ distilled water. The seeds were imbibed in distilled water in dark for the period of $12 \mathrm{~h}$ at $25 \pm 2{ }^{\circ} \mathrm{C}$. After $12 \mathrm{~h}$, the seeds were placed in petriplates for germination and maintained at $25^{\circ} \mathrm{C}$ for $4 \mathrm{~d}$ with $14 \mathrm{~h}$ photoperiod having $200 \mu \mathrm{M} \mathrm{m}^{-2} \mathrm{~S}^{-1}$ light intensity in a seed germinator. Healthy seedlings with terminal buds, two primary leaves and approximately 3 to 4 $\mathrm{cm}$ hypocotyls were selected. The primary roots were removed and the explants were put in $50 \mathrm{~mL}$ beakers containing distilled water and following standardized pretreating and treating solutions [comprising of Hydrgen peroxide $\left(\mathrm{H}_{2} \mathrm{O}_{2}\right)$, Salicylic acid (SA), Diphenyleneiodonium (DPI), Dimethylthiourea (DMTU) ] for 4 and $24 \mathrm{~h}$ respectively and maintained at $25 \pm 2$ ${ }^{\circ} \mathrm{C}$ with $14 \mathrm{~h}$ photoperiod and $200 \mu \mathrm{M} \mathrm{m}^{-2} \mathrm{~s}^{-1}$ light intensity in a growth chamber.

\begin{tabular}{|c|c|c|}
\hline $\begin{array}{l}\text { Experimental } \\
\text { Set }\end{array}$ & $\begin{array}{l}\text { Redox-manipulating conditions of } \\
\text { hypocotyl explant }\end{array}$ & $\begin{array}{l}\text { Treatment } \\
\text { Conditions }\end{array}$ \\
\hline a & Dist. $\mathrm{H}_{2} \mathrm{O}$ & Dist. $\mathrm{H}_{2} \mathrm{O}$ \\
\hline b & $500 \mu \mathrm{M} \mathrm{H}_{2} \mathrm{O}_{2}(4 \mathrm{~h})$ & $600 \mu \mathrm{M} \mathrm{SA}(24 \mathrm{~h})$ \\
\hline c & 1 mM DMTU (4 h) & $600 \mu \mathrm{M}$ SA $(24 \mathrm{~h})$ \\
\hline$d$ & $1 \mathrm{mM} \mathrm{DPI}(4 \mathrm{~h}) \mathrm{v}$ & $600 \mu \mathrm{M}$ SA (24 h) \\
\hline e & $500 \mu \mathrm{M} \mathrm{H}_{2} \mathrm{O}_{2}(4 \mathrm{~h})$ & Dist. $\mathrm{H}_{2} \mathrm{O}$ \\
\hline$f$ & Dist. $\mathrm{H}_{2} \mathrm{O}(4 \mathrm{~h})$ & $600 \mu \mathrm{M} \mathrm{SA}(24 \mathrm{~h})$ \\
\hline g & 1 mM DMTU (4 h) & Dist. $\mathrm{H}_{2} \mathrm{O}$ \\
\hline $\mathrm{h}$ & $1 \mathrm{mM}$ DPI (4 h) & Dist. $\mathrm{H}_{2} \mathrm{O}$ \\
\hline
\end{tabular}

Average number (no.) of ARF

Average no. of ARF were taken from 5 days old post treatment-raised tissues.

\section{RP-HPLC coupled photodiode assay of GA, ABA, JA}

To monitor the changes in Abscisic acid, Gibberelic acid and Jasmonate in the different treatment conditions, the differently treated explants were collected and crushed in $\mathrm{LN}_{2}$. Then, $400 \mathrm{mg}$ crushed powder was homogenized with $2 \mathrm{~mL}$ of cold acetonitrile and homogenates were kept at $4{ }^{\circ} \mathrm{C}$ for $12 \mathrm{~h}$. Then homogenate were centrifuge at $20000 \mathrm{rpm}$ for $10 \mathrm{~min}$ at $4{ }^{\circ} \mathrm{C}$. The supernatants were collected. The supernatant were transferred to a new centrifuge tube and mix it with $1.5 \mathrm{~mL}$ $0.1 \mathrm{M}$ phosphate buffer ( $\mathrm{pH} 7.1$ ) and kept at $-80{ }^{\circ} \mathrm{C}$ for $30 \mathrm{~min}$. After that, the supernatants were thawed adequately at $4^{\circ} \mathrm{C}$. The mixture is then extracted with $2.5 \mathrm{~mL}$ of ethyl acetate thrice after the addition of $1 \mathrm{~mL}$ of $\mathrm{HCl}$. The mixture is then centrifuged at $15,000 \mathrm{~g}$ for $10 \mathrm{~min}$. at $4{ }^{\circ} \mathrm{C}$ and the ethyl acetate phase is collected. The samples are then dried in Rotaryevaporator and dissolved in $1 \mathrm{~mL}$ of mobile phase (consisting 
of methanol and $\left.\mathrm{H}_{2} \mathrm{O}, 1: 1\right)$. The extracts were filtered through $0.2 \mathrm{~mm}$ membrane filter paper for HPLC from RP-HPLC in $\mathrm{C}_{18}$ column and UV-detection. $\mathrm{GA}_{3}$ and $\mathrm{ABA}$ and JA peak can be detected by using absorbance at $280 \mathrm{~nm}$. The mobile phase consisted of methanol and $0.2 \%$ phosphoric acid solution has flow rate of $0.8 \mathrm{~mL} / \mathrm{min}$. Standard $\mathrm{GA}_{3}, \mathrm{ABA}$, JA are used for the development of standard curve.

\section{Spectroflurometric estimation of total ROS and aspe- trophotometric estimation of proxidant $\left(\mathrm{H}_{2} \mathrm{O}_{2}\right)$}

For the extraction and estimation of total ROS and endogenous $\mathrm{H}_{2} \mathrm{O}_{2}$ the process of Kora and Bhattacharjee (2020) [5] was followed.

\section{Statistical analysis}

For Average no. of ARF, Results has been calculated as mean of five independent experiments with 15 explants per treatment \pm standard error from 5 days old post treatment-raised tissues. For estimation of Total ROS and endogenous $\mathrm{H}_{2} \mathrm{O}_{2}$, RP-HPLC assay of GA, ABA \& JA the experiments was carried after the end of pretreating and treating conditions i.e. at $28 \mathrm{hr}$ from the primary root removal. Total ROS and endogenous $\mathrm{H}_{2} \mathrm{O}_{2}$ studies was carried thrice and results has been calculated as mean of three independent experiments \pm standard error. Statistical analysis of the data for significance, the t-test paired two samples for means was done using Microsoft Excel 2010.

\section{Results}

Application of pro-oxidant $\mathrm{H} 2 \mathrm{O} 2$ (500 $\mu \mathrm{M})$ followed

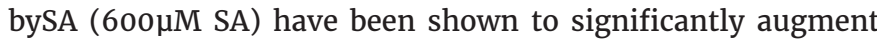
Adventitious Root Formation (ARF) by $197.2 \%$ as compared to untreated control, whereas $10 \times 10^{-4} \mathrm{M}$ DPI (an inhibitor of NADPH-oxidase) - $600 \mu \mathrm{M} \mathrm{SA}$ and $10 \times 10^{-4} \mathrm{M}$ DMTU (a free radical scavenger) - $600 \mu \mathrm{M}$ SA combination reduced the formation of ARF in hypocotyl explants of mung bean by 53.5 $\%$ and $52.1 \%$ (Figure $1,2 \mathrm{~A}, 3 \mathrm{~A}$ ). The individual treatment of $\mathrm{H}_{2} \mathrm{O}_{2}$ and SA have also found to increase the no. of ARF in hypocotyl explants of mung bean. DMTU and DPI also when treated individually further decreased the no. of AR [5].

The concentration of GA found to be increased in all treatment conditions as compared to the control one except in the individual treatment of NADPH-oxidase inhibitor (DPI), where it got decreased by $30.4 \%$. The concentration of GA in $500 \mu \mathrm{M} \mathrm{H}_{2} \mathrm{O}_{2}-600 \mu \mathrm{M}$ SA combinations increased by $162.4 \%$, by $157.8 \%$ in $1 \mathrm{mM}$ DMTU $-600 \mu \mathrm{M}$ SA and by $131.6 \%$ in $1 \mathrm{mM}$ DPI - $600 \mu \mathrm{M}$ SA combination. Individual treatment of $\mathrm{H}_{2} \mathrm{O}_{2}$ and SA showed increment in GA concentration by $107.82 \%$ and $219 \%$. The individual treatment of ROS scavenger (DMTU) showed surprised maximum increase by $1355 \%$ (Figure 2B). When plotted against the Endogenous $\mathrm{H}_{2} \mathrm{O}_{2}$ data and DCFDA oxidation data, it is clear that endogenous GA, endogenous $\mathrm{H}_{2} \mathrm{O}_{2}$ and total ROS increased in the $500 \mu \mathrm{M} \mathrm{H}_{2} \mathrm{O}_{2}-600 \mu \mathrm{M} \mathrm{SA}$ combination and both get lowered when the NADPH-oxidase gets inhibited by DPI (Figure 2B,3B).

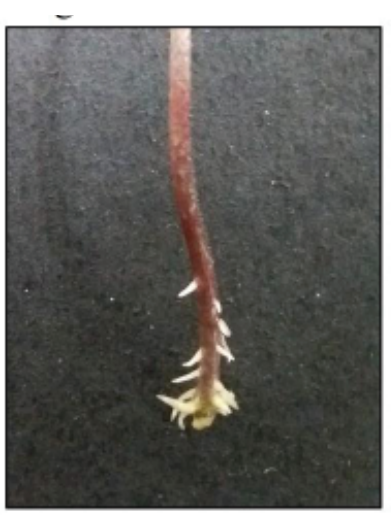

Control

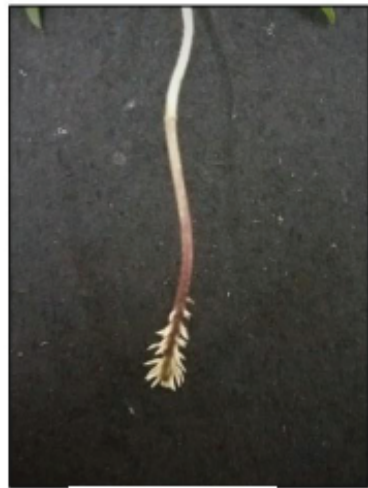

$500 \mu \mathrm{M} \mathrm{H}_{2} \mathrm{O}_{2}$

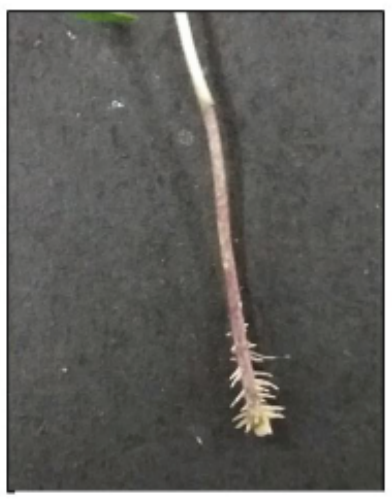

$500 \mu \mathrm{M} \mathrm{H}_{2} \mathrm{O}_{2}+600 \mu \mathrm{M} \mathrm{SA}$

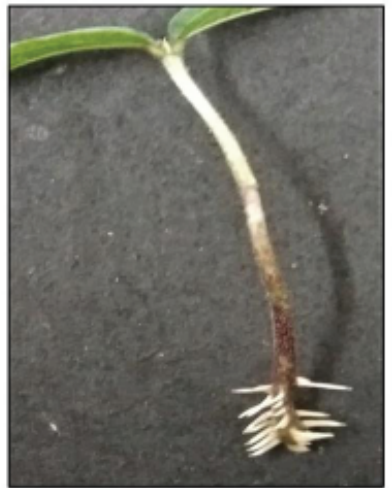

$600 \mu \mathrm{M} \mathrm{SA}$

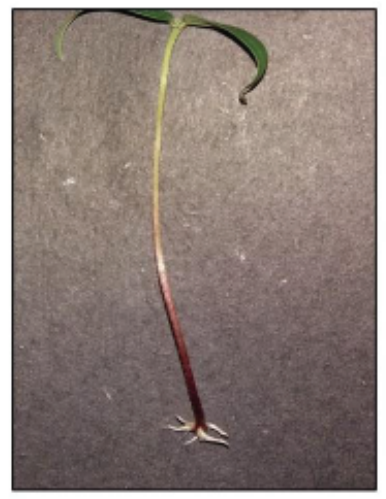

$1 \mathrm{mM} \mathrm{DMTU}+600 \mu \mathrm{M} \mathrm{SA}$

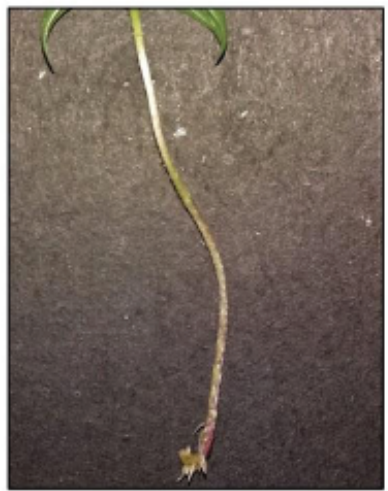

$1 \mathrm{mM}$ DMTU

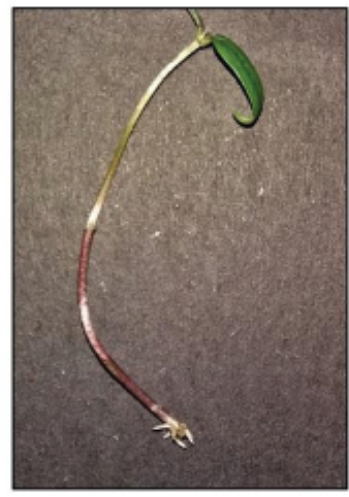

$1 \mathrm{mM} \mathrm{DPI}+600 \mu \mathrm{M} \mathrm{SA}$

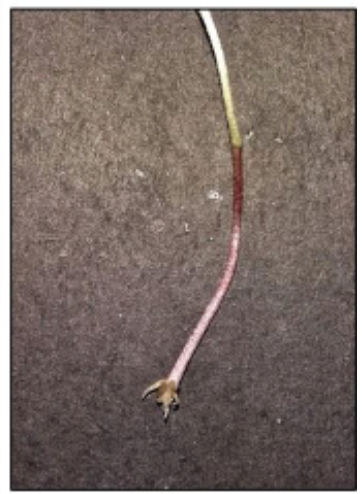

$1 \mathrm{mM}$ DPI

Figure 1: Micrograph showing impact of different redox manipulation on adventitious root formation in mung bean (Detail in the text). 
The Abscisic acid concentration found to be increased in 500 $\mu \mathrm{M} \mathrm{H}_{2} \mathrm{O}_{2}-600 \mu \mathrm{M}$ SA as well as in individual treatments of 500 $\mu \mathrm{M} \mathrm{H}_{2} \mathrm{O}_{2}$ and $600 \mu \mathrm{M}$ SA by $34.5 \%, 137.7 \%$ and $28.5 \%$. The ABA concentration gets decreased in both $1 \mathrm{mM}$ DMTU - $600 \mu \mathrm{M}$ SA combination and $1 \mathrm{mM}$ DPI - $600 \mu \mathrm{M}$ SA combination by 36.97 $\%$ and $32.8 \%$. Further, lone treatment of $1 \mathrm{mM}$ DMTU and 1 mM DPI also decreases ABA concentration by $7.7 \%$ and $45.4 \%$. When plotted against Endogenous $\mathrm{H}_{2} \mathrm{O}_{2}$ and DCFDA oxidation data, the ABA data corroborates well with later two and shows increase in the treatment conditions of $500 \mu \mathrm{M} \mathrm{H}_{2} \mathrm{O}_{2}$ and 600 $\mu \mathrm{M}$ SA and their combination treatment condition in compared to the control. The result clearly suggests the enhancement of the phytohormone ABA and endogenous ROS accumulation in $500 \mu \mathrm{M} \mathrm{H} 2 \mathrm{O} 2$ and $600 \mu \mathrm{M}$ SA and their combination treatment condition (Figure $2 \mathrm{C}, 3 \mathrm{C}$ ) and lower accumulation in DPI treated seedlings (Figure $2 \mathrm{C}, 3 \mathrm{C}$ ).

In case of jasmonic acid, it has not shown any clear trend in the results. It has been found to increase in the $500 \mu \mathrm{M} \mathrm{H}_{2} \mathrm{O}_{2}-$ $600 \mu \mathrm{M}$ SA by $29.8 \%$, in $1 \mathrm{mM}$ DMTU - $600 \mu \mathrm{M}$ SA by $136.4 \%$, in $1 \mathrm{mM}$ DPI - $600 \mu \mathrm{M}$ SA by $14.9 \%$, in $500 \mu \mathrm{M} \mathrm{H}_{2} \mathrm{O}_{2}$ individual treatment by $121.1 \%$, in $1 \mathrm{mM}$ DMTU individual treatment by $23.7 \%$ and got decreased in the $600 \mu \mathrm{M}$ SA and $1 \mathrm{mM}$ DPI individual treatments by $39.9 \%$ and $38.3 \%$. When the trends of Endogenous $\mathrm{H}_{2} \mathrm{O}_{2}$ and total ROS was compared with the trend ofABA accumulation in different treatment conditions, It is found to be opposite in relation to these (Figure 2D,3D).

\section{Discussion}

We have earlier reported that $\mathrm{H}_{2} \mathrm{O}_{2}$ has significant role in the adventitious root formation in SA treated hypocotyl explants of mung bean [5]. The $500 \mu \mathrm{M} \mathrm{H}_{2} \mathrm{O}_{2}-600 \mu \mathrm{M}$ SA combination has showed greater accumulation of $\mathrm{H}_{2} \mathrm{O}_{2}$ and total ROS in compared to the control one. Also where the DPI and DMTU has been used with or without SA, both $\mathrm{H}_{2} \mathrm{O}_{2}$ and total ROS found to be greatly reduced suggesting that mung bean explants require ROS signature with a distinct role of redox regulation through antioxidant buffering [5]. The interaction of ROS - PGRs like GA, ABA and JA during ARF has been less studied. There is little direct evidences of the cross talk of ROS and these PGR in ARF. However, many work have suggested the involvement of ROS, $\mathrm{ABA}$, JA and GA in the signaling pathway initiated by other plant growth hormones like auxin, ethylene etc. $[40,48]$. In this work, when redox status of SA treated hypocotyl explants of mung bean is manipulated by using pro-oxidant $\mathrm{H}_{2} \mathrm{O}_{2}$, NADPH-oxidase inhibitor, DPI and ROS scavenger, DMTU, no clear trend has been found in the endogenous accumulation of these PGRs in different treatment conditions. However, $500 \mu \mathrm{M}$ $\mathrm{H}_{2} \mathrm{O}_{2}-600 \mu \mathrm{M}$ SA combination which has shown significantly higher number of AR have also showed comparatively higher
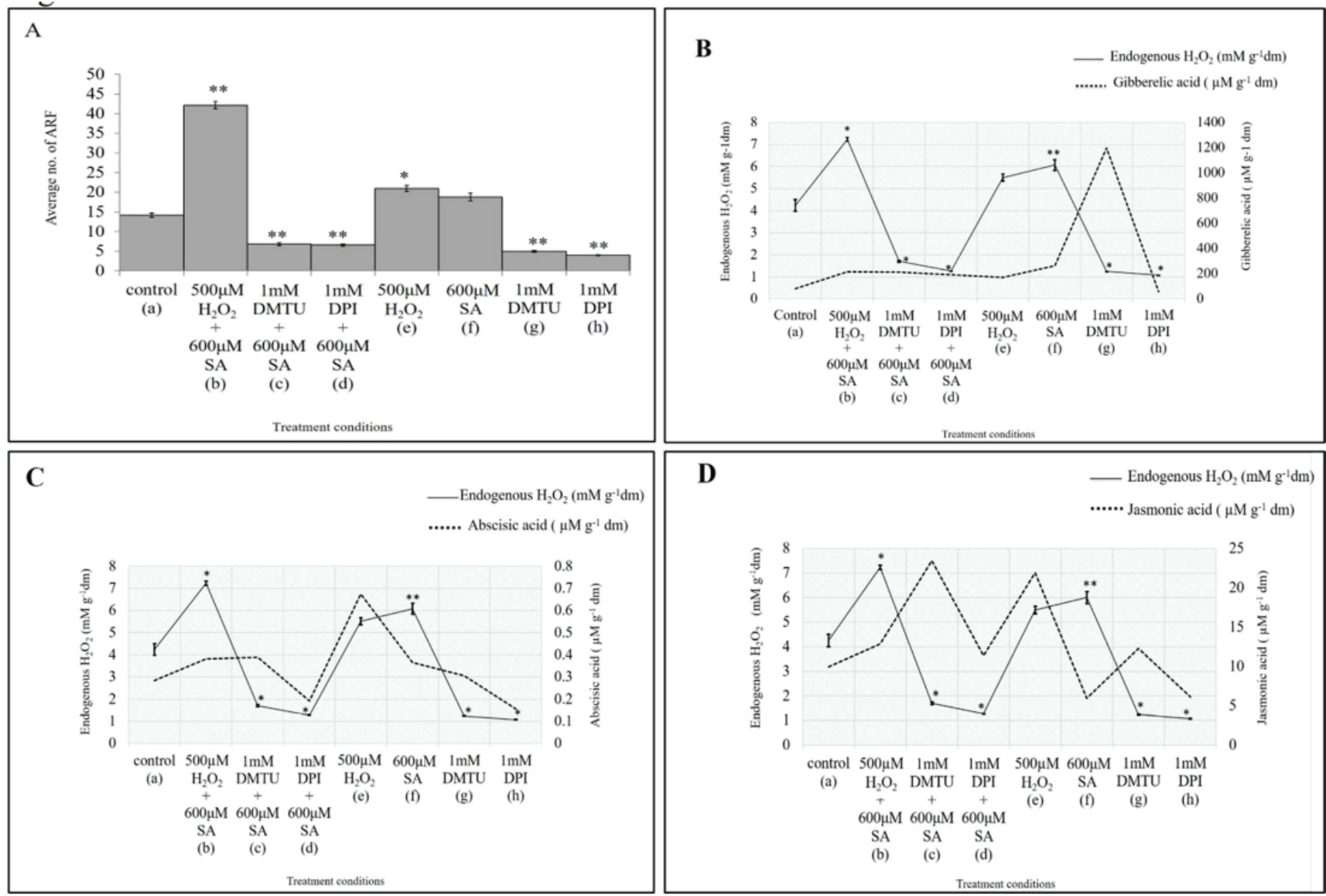

Figure 2: Figure showing ARF (A) and changes in the endogenous titer of $G A(B), A B A(C) J A(D)$ along with fluctuations of pro-oxidant $\left(\mathrm{H}_{2} \mathrm{O}_{2}\right)$ level under redox manipulation in mung bean. Results are mean of five and three replicates \pm standard error for ARF and endogenous $\mathrm{H}_{2} \mathrm{O}_{2}$ estimation respectively. ${ }^{*}$ represents significant changes from control at 0.01 level (t-test) and * represents significant changes from control at 0.05 level (t-test).

Citation: Kora D, Bhattacharjee S (2021) Redox regulation of adventitious root formation through downstream changes in hormonal system in mung bean [Vigna radiata (L.) R. Wilczek]. Ann Syst Biol 4(1): 005-012. DOI: https://dx.doi.org/10.17352/asb.000011 


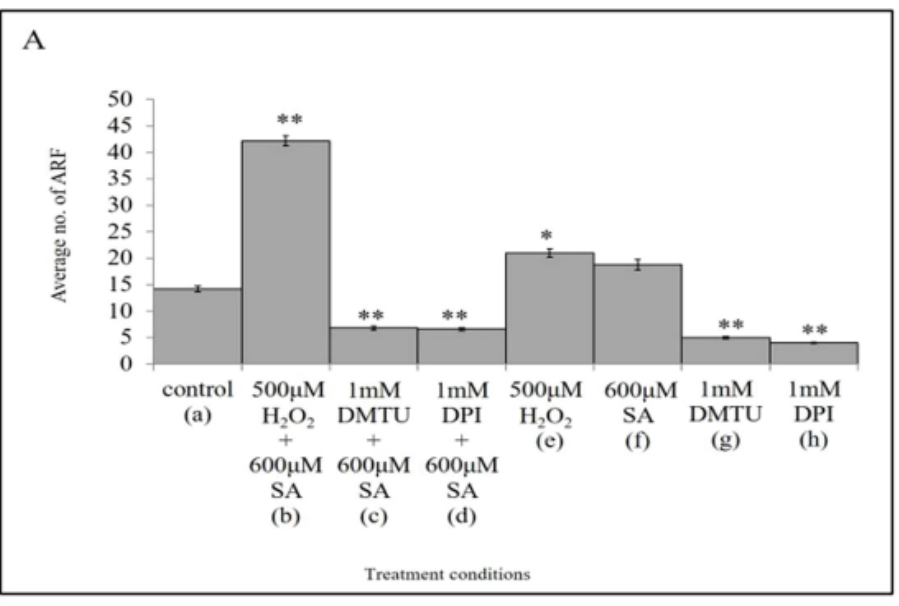

C
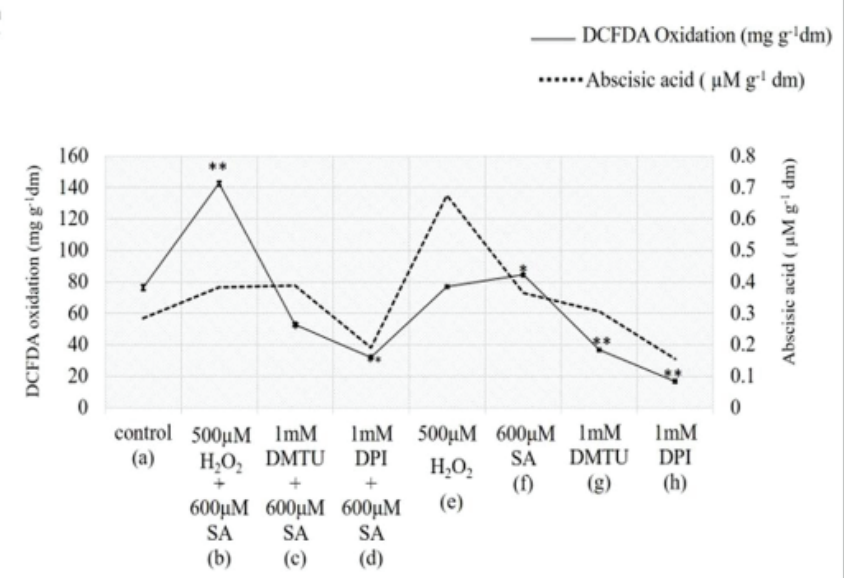

B

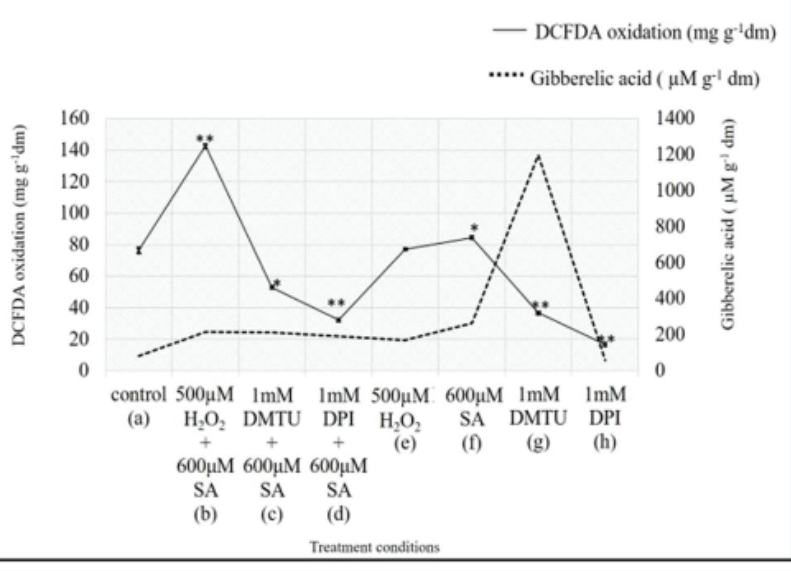

D

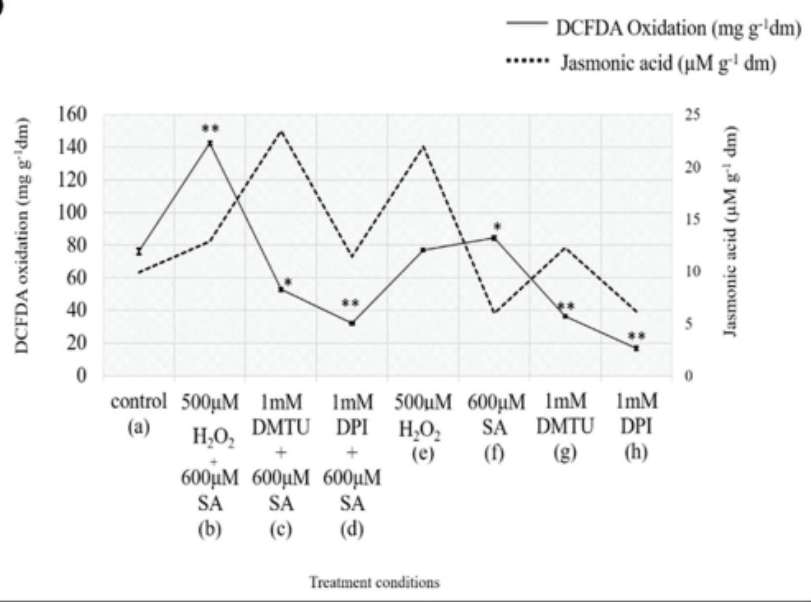

Figure 3: Figure showing ARF (A) and changes in endogenous titer of $G A(B), A B A(C)$ JA (D) along with fluctuations of the level of total ROS (assessed spectroflurometrically through DCFDA oxidation) under redox manipulation in mung bean. Results are mean of five and three replicates \pm standard error for ARF and Total ROS estimation respctively. ** represents significant changes from control at 0.01 level (t-test) and * represents significant changes from control at 0.05 level (t-test).

accumulation of GA, ABA and JA as well indicating their requirement in low concentration as suggested by previous work [5,35]. It is also evident from the results that DPI which inhibits the NADPH-oxidase that gives rise to $\mathrm{H}_{2} \mathrm{O}_{2}$ decreased the formation of necessary ROS and hence decreased the ARF. In the DPI treatment conditions, all of the three PGRs were found to be in lowest concentration indicating that ROS might be necessary for their up-regulation. The results may suggest that ROS, SA and PGRs like ABA, JA and GA acting downstream of other bonafide plant growth hormones and abiotic stress creating a large complex, sensitive signalling pathway that possess stimulatory and inhibitory effect on morphogenesis of ARF depending on their concentration and time.

\section{Conclusion}

Taken as a whole, we can conclude that there lies a complex sensitive hormonal network system where GA, ABA and JA cross talk with ROS in the morphogenesis of AR.

\section{Acknowledgement}

DK acknowledges University Grants Commission , New Delhi, india, for her Fellowship. SB acknowledge thanks to UGC
(CAS) as Coordinator for research funding to the Department of Botany, University of Burdwan, Burdwan, West Bengal [No.F.5-13/012 (SAP-II)].

\section{References}

1. Neill SJ, Desikan R, Clarke A, Hurst RD, Hancock JT (2002) Hydrogen peroxide and Nitric oxide as signaling molecule in plants. J Exp Bot 53: 1237-1247. Link: https://bit.ly/3bZvRO7

2. Steffens B, Kovalev A, Gorb SN, Sauter M (2012) Emerging roots alter epidermal cell fate through mechanical and reactive oxygen species signaling. Plant Cell 24: 3296-3306. Link: https://bit.ly/3pc2USU

3. Li SW, Xue LG, Xu SJ, Feng HY, An LZ (2009) Hydrogen peroxide acts as a signal molecule in the adventitious root formation of mung bean seedlings. Environ Exp Bot 65: 63-71. Link: https://bit.ly/3iyvGdA

4. Steffens B, Rasmussen A (2016) The physiology of adventitious roots. Plant Physiol 170: 603-617. Link: https://bit.ly/3iwbTf4

5. Kora D, Bhattacharjee S (2020) The interaction of reactive oxygen species and antioxidants at the metabolic interface in salicylic acid-induced adventitious root formation in mung bean [Vigna radiata (L.) R. Wilczek]. Journal of Plant Physiology Link: https://bit.ly/3iwbTf4

6. Kora D, Bhattacharjee S (2020) Redox gateway associated with adventitious root formation under stress and hormonal signalling in plants. Current Science 119: 462-472. Link: https://bit.ly/3o8hyJi. 
7. Wasternack C, Stenzel I, Hause B, Hause G, Kutter C, et al. (2006) The wound response in tomato: role of jasmonic acid. J Plant Physiol 163: 297-306. Link: https://bit.ly/3izUDp8

8. Orozco-Cárdenas ML, Narváez-Vásquez J, Ryan CA (2001) Hydrogen Peroxide Acts as a Second Messenger for the Induction of Defense Genes in Tomato Plants in Response to Wounding, Systemin, and Methyl Jasmonate. The Plant Cell 13: 179-191. Link: https://bit.ly/3951dRu.

9. Quan LJ, Zhang B, Shi WW, Li HY (2008) Hydrogen peroxide in plants: a versatile molecule of the reactive oxygen species network. J Integr Plant Biol 50: 2-18. Link: https://bit.ly/2YONbdk.

10. SantosMacedo E, Cardoso HG, Hernández A, Peixe A, Polidoros A, et al. (2009) Physiologic responses and gene diversity indicate olive alternative oxidase as a potential source for markers involved in efficient adventitious root induction Physiol Plant 137: 532-552. Link: https://bit.ly/3iAeMva.

11. Li SW, Xue LG (2010) The interaction between $\mathrm{H}_{2} \mathrm{O}_{2}$ and $\mathrm{NO}, \mathrm{Ca} 2+, \mathrm{cGMP}$, and MAPKs during adventitious rooting in Mung bean seedlings. In Vitro Cell Dev Biol Plant 46: 142-148. Link: https://bit.ly/3qLRHbl

12. Liao WB, Xiao HL, Zhang ML (2010) Effect of Nitric Oxide and Hydrogen Peroxide on Adventitious Root Development from Cuttings of Ground-Cover Chrysanthemum and Associated Biochemical Changes. J Plant Growth Regul 29: 338-348. Link: https://bit.ly/3956IVA

13. She XP, Huang AX, Ren $Y$ (2010) Hydrogen peroxide generated by copper amine oxidase involved in adventitious root formation in mung bean hypocotyl cutting. Aust J Bot 58: 656-662. Link: https://bit.ly/39TLvHV

14. Li S, Xue L, Xu S, Feng H, An LG (2007) Hydrogen peroxide involvement in formation and development of adventitious roots in cucumber. Plant Growth Regul 52: 173-180. Link: https://bit.ly/364hBQi

15. Qi X, Li Q, Ma X, Qian C, Wang H, et al. (2018) Water logging-induced adventitious root formation in cucumber is regulated by ethylene and auxin through reactive oxygen species signaling. Plant Cell Environ 42: 1458-1470. Link: https://bit.ly/3sPvPyd

16. Yang W, Zhu C, Ma X, Li G, Gan L, et al. (2013) Hydrogen Peroxide Is a Second Messenger in the Salicylic Acid-Triggered Adventitious Rooting Process in Mung Bean Seedlings. Plos One 8. Link: https://bit.ly/2Y58gDw

17. Singh SP (1993) Effect of non-auxinic chemicals on root formation in some ornamental plant cuttings. Adv Hort For 3: 207

18. Gutiérrez-Coronado M, Trejo CL, Larqué-Saavedra A (1998) Effects of salicylic acid on the growth of roots and shoots in soybean. Plant Physiol Biochem 36 563-565.

19. Still SM, Dirr MA, Gartner JB (1976) Phytotoxic effects of several bark extracts on mung bean and cucumber growth. Journal-American Society of Horticultural Science 101: 34-37. Link: https://bit.ly/2NuDstB

20. Li L (1995) Effects of resorcinol and salicylic acid on the formation of adventitious roots on hypocotyl cutting of Vigna radiate. Journal of Tropical and Subtropical Botany 3: 67-71.

21. DeKlerk GJ, Guan HY, Huisman P, Marinova S (2011) Effects of phenolic compounds on adventitious root formation and oxidative decarboxylation of applied indoleacetic acid in Malus 'Jork 9'. Plant Growth Regulation 63: 175 185. https://bit.ly/3pa3ct9.

22. Kling GJ, Myer MM (1983) Effects of phenolic compounds and IAA on adventitious root initiation in cuttings of Phaseolus-aureus. Acer HortScience 18: 352-354.

23. Dong CJ, Liu XY, Xie LL, Wang LL, Shang QM (2020) Salicylic acid regulates adventitious root formation via competitive inhibition of the auxin conjugation enzyme CsGH3.5 in cucumber hypocotyls. Planta 252: 75. Link: https://bit.ly/3p2UwF3
24. Kang SM, Jung HY, Kang YM, Yun DJ, Bahk JD, et al. (2004) Effects of methy jasmonate and salicylic acid on the production of tropane alkaloids and the expression of PMT and $\mathrm{H6H}$ in adventitious root cultures of Scopolia parviflora. Plant Sciences 166: 745-751. Link: https://bit.ly/3sPH4qa

25. Guan L, Tayengwa R, Cheng Z, Ann Peer W, Murphy AS, et. al,. (2019) Auxin regulates adventitious root formation in tomato cuttings. BMC Plant Biol 19: 435. Link: http://bit.ly/3qFKI4m.

26. Chen WP, Silva H, Klessig RF (1993) Active oxygen species in the induction of plant systemic acquired resistance by SA. Science 262: 1883-1886. Link: https://bit.ly/2LNjEkZ

27. Lee S, Park CM (2010) Modulation of reactive oxygen species by salicylic acid in Arabidopsis seed germination under high salinity. Plant Signaling Behavio 5: 1534-1536. Link: https://bit.ly/3piBQkZ

28. Ruan J, Zhou Y, Zhou M, Yan J, Khurshid M, et al. (2019) Jasmonic Acid Signaling Pathway in Plants. Int J Mol Sci 20: 2479. Link: http://bit.ly/3ivyKaA

29. Gupta R, Chakrabarty SK (2013) Gibberellic acid in plant:Still a mystery unresolved. Plant Signal Behav 8: e25504. Link: https://bit.ly/399lqWt

30. Bewley JD (1997) Seed Germination and Dormancy. Plant Cell 9: 1055-1066. Link: http://bit.ly/3qEibfp

31. Ogawa M, Hanada A, Yamauchi Y, Kuwahara A, Kamiya $Y$, Yamaguchi S (2003) Gibberellin biosynthesis and response during Arabidopsis seed germination. Plant Cell 15: 1591-1604. Link: http://bit.ly/3p60G7q

32. Kucera B, Cohn MA, Leubner-Metzger G (2005) Plant hormone interaction during seed dormancy release and germination. Seed Sci Res 15: 281-307. Link: https://bit.ly/3c0oXYI

33. Chhun T, Aya K, Asano K, Yamamoto E, Morinaka Y, et al. (2007) Gibberellin regulates pollen viability and pollen tube growth in rice. Plant Cell 19: 38763888. Link: https://bit.ly/3bYDXX6

34. White CN, Proebsting WM, Hedden P, Rivin CJ (2000) Gibberellins and seed development in maize. I. Evidence that gibberellin/abscisic acid balance governs germination versus maturation pathways. Plant Physiol. 122:1081-8. Link: https://bit.ly/2LRwPBf

35. Nanda KK, Purohit AN, Bala A (1967) Effect of photoperiod, auxins and gibberellic acid on rooting of stem cuttings of Bryophyllum tubiflorum. Physiol Plantarem 20: 1096-1102. Link: https://bit.ly/3o33WiE

36. Eriksen EN (1971) Promotion of root initiation by gibberellin. Roy. Vet Agric Univ Yrbk, Kandru, P. and W. Copenhagen (Eds.) Jhon Willey and Sons, New York 50-59.

37. Nanda KK, Anand VK, Chibbar RN (1972) The Promotive Effect of Gibberellic Acid on the Production of Adventitious Roots on Stem Cuttings of Ipomoea fistulosa. Planta 105: 360-363. Link: https://bit.ly/2XXYDXb

38. Hansen J (1976) Adventitious Root Formation Induced by Gibberellic Acid and Regulated by the Irradiance to the Stock Plants. Physiologia Plantarum 36: 77 81. Link: https://bit.ly/39Rrl1o

39. Hansen J (1975) Light dependent promotion and inhibition of adventitious root formation by gibberellic acid. Planta 123: 203-205. Link: https://bit.ly/3piDVOh

40. Pawlicki N, Welander M (1992) The effects of benzyladenine and gibberellic acid on adventitious root formation in apple stem discs. Agronomie, EDP Sciences 12: 783-788. Link: https://bit.ly/3iAQe5y

41. Adhikari UK, Bajracharya D (1978) Interaction of Gibberellic acid and Indole3-acetic acid on root formation in Pea (Pisum sativum L.) epicotyle cutting Planta 143: 331-332. Link: http://bit.ly/3sL6eGE

42. Kim H, Cha HC (2015) Effect of Gibberellin on the Adventitious Root Formation from the Leaves-derived Calli in Persicaria perfoliata. Journal of Life Science. Link: http://bit.ly/39L2nAw

43. Brian PW, Hemming HG, Radley M (1955) A physiological comparison of gibberellic acid with some auxins. Physiol Plantarum 8: 899-912. Link: https://bit.ly/362dofL

Citation: Kora D, Bhattacharjee S (2021) Redox regulation of adventitious root formation through downstream changes in hormonal system in mung bean [Vigna radiata (L.) R. Wilczek]. Ann Syst Biol 4(1): 005-012. DOI: https://dx.doi.org/10.17352/asb.000011 
44. Brian PW, Hemming HG, Radley M (1960) Inhibition of rooting of cuttings by gibberellic acid. Ann Bot 24: 407-419. Link: https://bit.ly/3pi997m

45. Murashige $T$ (1964) Analysis of the inhibition of organ formation in tobacco tissue culture by gibberellin. Physiol Plantarem 17: 636-643. Link: https://bit.ly/2YeiYHX

46. Fernqvist I (1966) Studies on factors in adventitious root formation. Ann Agric Coll Sweden 82: 109-244.

47. Nanda KK, Purohit AN, Mehrotra K (1968) Effect of sucrose, auxins and gibberellic acid on rooting of stem segments of Popvlus nigra under varying light conditions. Plant Cell Physiol 9: 735-743. Link: https://bit.ly/2Nq04LX.

48. Haissig BE (1972) Meristematic Activity, during Adventitious Root Primordium Development influences of endogenous auxin and applied gibberellic acid. Plant Physiol 49: 886-892. Link: http://bit.ly/3o7ztja

49. Fath A, Bethke PC, Jones RL (2001) Enzymes That Scavenge Reactive Oxyge Species Are Down-Regulated Prior to Gibberellic Acid-Induced Programmed Cell Death in Barley Aleurone. Plant physiology. Link: https://bit.ly/3qKnmdV

50. Bethke PC, Jones RL (2001) Cell death of barley aleurone protoplasts is mediated by reactive oxygen species. Plant Journal 25: 19-29. Link: https://bit.ly/3bWQIBy

51. Busov V, Meilan R, Pearce DW, Rood SB, Ma C, et al. (2006) Transgenic modification of gai or rgl1 causes dwarfing and alters gibberellins, roo growth, and metabolite profiles in Populus. Planta 224: 288-299. Link: https://bit.ly/3sKhumu

52. Mehrotra R, Bhalothia $P$, Bansal $P$, Basantani M K , Bharti V, Mehrotra $S$ (2014) Abscisic acid and abiotic stress tolerance - different tiers of regulation. J Plant Physiol 171: 486-496. Link: https://bit.ly/360dOn3

53. Zhao Y, Chen K, Li G-J, Bressan RA, Song C-P, Zhu J-K (2020) Abscisic acid dynamics, signaling, and functions in plants. Journal of Integrative Plant Biology 62: 25-54. Link: https://bit.ly/3ivtGmA

54. Sah SK, Reddy KR, Li J (2016) Abscisic Acid and Abiotic Stress Tolerance in Crop. Plants Front Plant Sci 7: 57. Link: https://bit.ly/2M9bmU8

55. Li S, Leng Y, Feng L, Zeng XY (2014) Involvement of abscisic acid in regulating antioxidative defense systems and IAA-oxidase activity and improving adventitious rooting in mung bean [Vigna radiata (L.) Wilczek] seedlings under cadmium stress. Environ Sci Pollut Res 21:525-537. Link: https://bit.ly/3iwfMka

56. Cao Z, Huang B,Wang QY, Xuan W, Ling TF, et al. (2007) Involvement of carbon monoxide produced by heme oxygenase in ABA-induced stomatal closure in Vicia faba and its proposed signal transduction pathway. Chin Sci Bull 52: 2365-2373. Link: https://bit.ly/2Y2xjqA

57. Li XP, Xu QQ, Liao WB, Ma ZJ, Xu XT, et al. (2016) Hydrogen peroxide is involved in abscisic acid-induced adventitious rooting in cucumber (Cucumis sativus L.) under drought stress. Journal of Plant Biology 59: 536-548. Link: Link: https://bit.ly/39MXHdC

58. Li C, Bian B, Gong T, Liao W (2018) Comparative proteomic analysis of key proteins during abscisic acid-hydrogen peroxide-induced adventitious rooting in cucumber (Cucumis sativus L.) under drought stress. Journal of Plant Physiology 229: 185-194. Link: https://bit.ly/3p7EwS3

59. Yasmin S, Ahmed B , Soomro, R (2003) Influence of ABA, Gibberellin and Kinetin on IAA Induced Adventitious Root Development on Hypocotyl Cuttings of Mung bean. Biotechnology 2: 37-43. Link: https://bit.ly/390S3b2

60. Steffens B, Wang J, Sauter M (2006) Interactions between ethylene, gibberellin and abscisic acid regulate emergence and growth rate of adventitious roots in deepwater rice. Planta 223: 604-612. Link: https://bit.ly/3qSV9BN

61. Guan L, Tayengwa R, Cheng Z(Max), Peer WA, Murphy AS, Zhao M (2019)
Auxin regulates adventitious root formation in tomato cuttings. BMC Plant Biology. Link: http://bit.ly/3qFKI4m

62. Hoffmann-Benning S, Kende $\mathrm{H}$ (1992) On the role of abscisic acid and gibberellin in the regulation of growth in rice. Plant Physiol 99: 1156-1161. Link: http://bit.ly/3ccFg55

63. Azuma T, Hirano T, Deki Y, Uchida N, Yasuda T, et al. (1995) Involvement of the decrease in levels of abscisic acid in the internodal elongation of submerged floating rice. J Plant Physiol 146: 323-328. Link: https://bit.ly/39WbSNo

64. Cox MC, Benschop JJ, Vreeburg RA, Wagemaker CA, Moritz T, et al. (2004) The role of ethylene, auxin, abscisic acid, and gibberellin in the hyponastic growth of submerged Rumex palustris petioles. Plant Physiol 136: 2948-2960. Link: https://bit.ly/364glHw

65. Thompson AJ, Thorne ET, Burbidge A, Jackson AC, Sharp RE, et al. (2004) Complementation of notabilis, an abscisic acid-deficient mutant of tomato: Importance of sequence context and utility of partial complementation 27 459-471.Link: https://bit.ly/3p9DW6k

66. Zhang Y, Zhu H, Zhang Q, Li M, Yan M, et al. (2009) Phospholipase D_1 and phosphatidic acid regulate NADPH oxidase activity and production of reactive oxygen species in ABA-mediated stomatal closure in Arabidopsis. Plant Cell 21: 2357-2377. Link: https://bit.ly/3sKnlYZ

67. Wasternack C, Hause B (2013) Jasmonates: Biosynthesis, perception, signal transduction and action in plant stress response, growth and development. An update to the 2007 review in Annals of Botany. Ann Bot 111: 1021-1058. Link: https://bit.ly/2LTH2Np

68. Campos ML, Kang JH, Howe GA (2014) Jasmonate-triggered plant immunity. J Chem Ecol 40: 657-675. Link: https://bit.ly/2KzcyzG

69. Creelman RA, Tierney ML, Mullet JE (1992) Jasmonic acid/methyl jasmonate accumulate in wounded soybean hypocotyls and modulate wound gene expression. Proc Natl Acad Sci USA 89: 4938-4941. Link: https://bit.ly/39YrW1s

70. Chen Q, Westfall CS, Hicks LM, Wang S, Jez JM (2010) Kinetic basis for the conjugation of auxin by a $\mathrm{GH} 3$ family indole-acetic acid-amido synthetase. J Biol Chem 285: 29780-29786. Link: http://bit.ly/2MaP8RG

71. Westfall CS, Herrmann J, Chen Q, Wang S, Jez JM (2010) Modulating plant hormones by enzyme action. Plant Signal Behav 5: 1607-1612. Link: https://bit.ly/3izFlvl

72. Wang S, Bai Y, Shen C, Wu Y, Zhang S, et al. (2010) Auxin-related gene families in abiotic stress response in Sorghum bicolor. Funct Integr Genom 10: 533546. Link: http://bit.ly/3sIBENP

73. Gutierrez L, Mongelard G, Floková K, Păcurar DI, Novák O, et. al., (2012) Auxin Controls Arabidopsis Adventitious Root Initiation by Regulating Jasmonic Acid Homeostasis. Plant Cell 24: 2515-2527. Link: https://bit.ly/3p75Pw3

74. Lischweski S, Muchow A, Guthorl D, Hause B (2015) Jasmonates act positively in adventitious root formation in petunia cuttings. BMC Plant Biol 15: 229 Link: https://bit.ly/3sLa2rq

75. Wang P, Ma L, Wang S, Li L, Wang Q, et al. (2019) Identification and analysis of a candidate WRKY transcription factor gene affecting adventitious root formation using association mapping in Catalpa Scop. DNA Cell Biol 38: 297 306. Link: https://bit.ly/3sSXCOr

76. Kloth KJ, Wiegers GL, Busscher-Lange J, van Haarst JC, Kruijer W, et al (2016) AtWRKY22 promotes susceptibility to aphids and modulates salicylic acid and jasmonic acid signalling. J Exp Bot 67: 3383-3396. Link: https://bit ly/3bYIB7u

77. Mhimdi M, Pérez-Pérez JM (2020) Understanding of Adventitious Roo Formation: What Can We Learn From Comparative Genetics? Front Plant Sci 11: 582020. Link: http://bit.ly/3o3Kp1p

Copyright: @ 2021 Kora D, et al. This is an open-access article distributed under the terms of the Creative Commons Attribution License, which permits unrestricted use, distribution, and reproduction in any medium, provided the original author and source are credited.

Citation: Kora D, Bhattacharjee S (2021) Redox regulation of adventitious root formation through downstream changes in hormonal system in mung bean [Vigna radiata (L.) R. Wilczek]. Ann Syst Biol 4(1): 005-012. DOI: https://dx.doi.org/10.17352/asb.000011 